\title{
NON-CONTRIBUTORY SOCIAL SECURITY APPLICATION FOR ELDERLY AND INDIVIDUALS WITH DISABILITIES': THE CASE OF TURKEY
}

\section{PRIMMSIZZ UYGULAMALARLA YAŞLI VE ENGELLİLERİN SOSYAL GÜVENLİĞİ: TÜRKIYE ÖRNEĞI}

\author{
Mete Kaan NAMAL ${ }^{1}$, Aynur YUMURTACI ${ }^{2}$, Bülent ARPAT $^{3}$
}
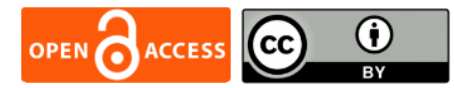

1. Doç. Dr., Akdeniz Üniversitesi,

namal@akdeniz.edu.tr,

https://orcid.org/0000-0002-0937-8355

2. Dr,, aynur.yumurtaci@gmail.com,

https://orcid.org/0000-0003-0277-5750

3. Dr. Öğr. Üyesi, Bandırma 17 Eylül Üniversitesi, bulent.arpat@gmail.com,

https://orcid.org/0000-0002-3512-9969

\begin{tabular}{|c|c|}
\hline Makale Türü & Article Type \\
\hline Araştırma Makalesi & Research Article \\
\hline Başvuru Tarihi & Application Date \\
\hline 01.10 .2020 & 10.01 .2020 \\
\hline Yayına Kabul Tarihi & Admission Date \\
\hline 06.10 .2021 & 10.06 .2021 \\
\hline & \\
\hline https://doi.org/10.3 & akuiibf. 803737 \\
\hline
\end{tabular}

https://doi.org/10.30798/makuiibf.803737

\begin{abstract}
In Turkey, although elderly and/or individuals with disabilities take place within the non-contributory system and them having the same requirements to claim their monthly payments, the amount of individuals with disabilities' Monthly Payments which were paid until June 2018 have always exceeded the Elderly Persons' Monthly Premiums. In contrast, afterwards the 2016 amendment, the individuals with disabilities have faced injustice with the "per capita income" principle, which was implemented in favor of the elderly. With this study, we aim to emphasize that with the adoption of the Individuals with Disabilities' Law of 2005, the conditions and amount of premiums to claim Elderly and Individuals with Disabilities' Monthly Benefits are inconsistent with the social justice principle. Thus, we state that the amount of monthly payments paid to the disadvantaged elderly people and individuals with disabilities are insufficient to have them reach the minimum living standards. Accordingly, it became evident that to fulfill the social justice principle in paying the elderly and individuals with disabilities' monthly premiums within the non-contributory system in Turkey, indexation has to be carried at $40 \%$ rate of the "per capita net income".
\end{abstract}

Keywords: Social Security, Disadvantaged Groups, Monthly Payments For The Elderly, Monthly Payments For The Individuals With Disabilities, Law No.2022.

\section{Öz}

Türkiye'de de muhtaç, yaşlı ve(ya) engellilerin sosyal güvenliği primsiz sistem kapsamında olup aylıkları hak etme șartları aynı olmakla beraber, Haziran 2018'e kadar ödenen Engelli Aylıklarının miktarı, hep Yaşlı Aylığı üzerinde seyretmiştir. Buna mukabil, 2016 yılında yapılan değișiklik sonrasında, yaşlılar lehine uygulanan "kiși başına düșen gelir" ilkesi ile birlikte bu defa da engelliler haksızlığa uğramıștır. Bu çalışmada Türkiye'de 2005 tarihli Engelliler Kanunu'nun kabulü ile birlikte, Yaşlı ve Engelli Aylığı almaya yönelik şartların ve ödeme miktarlarının, sosyal adalet ilkesine aykırı olduğunu vurgulamak amaçlanmaktadır. Böylece muhtaç yaşlılara ve engellilere ödenen aylıkların miktarının onları asgari hayat standardına kavuşturmada yetersiz olduğu ortaya konmaktadır. Çalıșmada, bütün dezavantajlı sosyal grupları asgari hayat standardına kavuşturabilmek için "kişi başına düşen gelir" ilkesinin muhtaç durumdaki her birey için geçerli olması gerektiğinin altı da çizilmektedir. Bu doğrultuda, Türkiye'de primsiz sistem kapsamındaki yaşlı ve engelli aylıklarının ödenmesinde sosyal adalet ilkesinin yerine getirilmesi için "kişi başına düşen ortalama (net) millî gelir"in \%40’ı üzerinden endeksleme yapılması gerektiği ortaya çıkmıştır.

Keywords: Sosyal Güvenlik, Dezavantajlı Gruplar, Yaşlı Aylı̆̆, Engelli Aylıkları, 2022 Sayll Kanun. 


\section{Çalışmanın Amacı}

\section{GENIŞLETILMIŞ ÖZET}

Sosyal devlet sorumluluğu ve sosyal adalet ilkesi gereğince muhtaç durumdaki yaşlı ve engellilere, asgari hayat standardı sağlamak amacıyla prim karşılığı olmayan "aylık ödemeleri" yapılmaktadır. Bu araştırmanın amacı, yaşlı ve engellilere yapılan aylık ödemelerini hem tutar hem de sosyal adalet açısından irdelemek, aksayan yönleri tespit etmek ve çözüm önerilerinde bulunmaktır. Araştırma, 2022 sayılı kanun kapsamında 2013-2019 yılları arası engelli ve yaşlılara yönelik yapılan yardımların ve uluslararası örneklerin incelenmesi ile yürütülmüştür.

\section{Araştırma Soruları}

2022 sayılı Kanun kapsamındaki iki dezavantajlı sosyal grup olan yaşlı ve engellilere ödenen aylıklar arasında farklılık var mıdır? Her iki grupta "kişi başına düşen ortalama (net) millî gelir" ilkesine uygun ödeme almakta mıdır? Ödeme tutarları, sosyal adalet ilkesine uygun mudur? Diğer ülke uygulamalarında yaşlı ve engellilere yönelik primsiz ödeme uygulamaları hangi düzeylerde ve usulesaslar çerçevesinde yürütülmektedir? Primsiz uygulamalar kapsamındaki tüm dezavantajlı gruplara adil bir sosyal yardım hesaplama yöntemi kullanılabilir mi?

\section{Literatür Araştırması}

Özellikle herhangi bir geliri olmayan ve dolayısıyla maddî yönden kendi kendilerine yeterli olmayan yaşlı ve engelliler için, sosyal güvenlik sistemlerinin varlığı son derece önemlidir. Primsiz sosyal güvenlik uygulaması, Dünya'da emekli aylığı almayan yaklaşık \%52'lik kesim için yoksulluğa karşı güvence sağlayan sosyal güvenlik tekniklerinden biridir. Türkiye'de yaşlı ve engelli nüfusunun giderek artması, sosyal güvenlik sisteminde bu grupları ön plana çıkarmaktadır. Yaşlı ve engelli dostu sosyal güvenlik sistemleri, yoksul durumdaki yaşlı ve engellilere sadece maddî güvence sağlamanın ötesinde, onların sosyal adalet ilkelerine uygun olarak toplum hayatına eşit değerde katılmalarının da teminatıdır.

\section{Yöntem}

$\mathrm{Bu}$ çalışma nitel araştırma deseninde ve durum çalışması tekniği ile gerçekleştirilmiştir. Veri toplama için belgesel taramadan faydalanılmış ve doküman analizi yoluyla değerlendirilmiştir. $\mathrm{Bu}$ çerçevede yıllar itibariyle yapılan mevzuat değişiklikleri ve bu değişikliklerin oluşturduğu eşitsizlikler tablolar vasıtasıyla karşılaştırmalı olarak ortaya konmuştur. Araştırma, sosyal yardım alan kesimlerin başında gelen yaşlılar ve engellilerin uğradığı eşitsizliği ortaya koyan oldukça kapsamlı bir içerikten oluşmaktadır. Araştırma içinde farklı coğrafyadaki ülkelerden Norveç, Mısır, Güney Kore, ABD ve Peru gibi ülkelerin engelli ve yaşlılara yönelik uygulama örnekleri de incelenerek öneriler geliştirilmiştir.

\section{Sonuç ve Değerlendirme}

2022 sayılı Kanunda, 2005 tarihli Engelliler Kanunu'nun kabulü ile birlikte yapılan bazı değişiklikler sebebiyle, yaşlı ve engelli maaşlarında uygulanan eşit şartlar, engellilerin lehine değiştirilmiş ve engelli aylıklarında yaşlı1ık maaşına göre bir artış meydana gelmiştir. 2016 yılında ise, 
yaşlılar lehine alınmış "kişi başına düşen gelir" uygulamasının engelliler için düşünülmemiş olması, engelliler açısından eşitlik ilkesine aykırı bir durum ortaya çıkarmıştır. Sosyal adalet ilkesi doğrultusunda, muhtaç durumdaki yaşlı ve engellilere asgari hayat standardı sağlayıcı Aylık uygulamalarının "kişi başına düşen ortalama (net) millî gelir" ilkesine göre şekillendirilmesi ve primsiz uygulamalar kapsamındaki bütün dezavantajlı sosyal grupların aynı esaslar doğrultusunda muhtaçlık kriterlerine tâbi tutularak, eşit miktarda kamusal sosyal yardım almaları sağlanmalıdır. Bununla da yetinilmemeli, Kamusal Sosyal Yardım kapsamında ödenen bütün Aylıklarda, dezavantajlı sosyal grupların asgari hayat standardını yükseltmek amacıyla, "Kişi Başına Düşen Ortalama Gelir” prensibi benimsenmelidir. Böylece bütün dezavantajlı sosyal kesimlere mensup kişilerin aylık gelirleri eşit seviyeye gelecek, diğer gelir gruplarının ortalama refah seviyelerine önemli derecede yaklaşacak ve sosyal adalet hedefine de ulaşılacaktır. 


\section{INTRODUCTION}

Social security in general is the system of measures usually comprised by the government through variant social protection models in reaction to a person's temporary or permanent deprivation of payment because of social risks that put a person through a disadvantaged position such as an illness, disability, old age, death, and unemployment. The increasing elderly and individuals with disabilities population brings these social groups to the foreground within the social security system in Turkey as is the case in the world. The existence of social security systems is especially important for the elderly and individuals with disabilities who do not have an income and thus not self-sufficient. The elderly and individuals with disability friendly social security systems are the safety net of the poor, elderly and individuals with disabilities to take part in the social life equally as per the social justice principles beyond just providing financial security. Just as it is the case in the whole world, when we say social security systems, two models come to mind which are the Contributory Regime (Social Security System) and Non-Contributory Regime (Public Welfare System). The common purpose of these two regimes is to prevent and/or appease the poverty risk to arise by resorting to different methods. The social security of one of the most disadvantaged social classes, the destitute elderly and individuals with disabilities, is mostly provided through the Non-Contributory Regime (Seyyar, 2015).

People belonging to the disadvantaged social groups, contrary to other individuals of the society, cannot easily have access to many implements that can provide them socio-economic sufficiency within their own means. The elderly and individuals with disabilities taking the top spot, the most important attribute of disadvantaged persons' is their lack of the most basic economic, cultural and social resources because of their physical, corporal, psychological and/or mental deficiencies (Mayer, 2003; East Marmara Development Agency, 2011). Thus, especially because advance old age and severe disability are permanent situations and unable to be eliminated, it seems difficult for the elderly and individuals with disabilities to leave their disadvantaged positions (Aysoy, 2004). Therefore, the most important obligation of a social law state is to at least enforce social security measures to prevent the elderly and individuals with disabilities to become destitute and be forced out of the social life; even though it cannot completely destroy the disadvantaged position which is the result of old age and disability and have medical reasons (Nutsubidze and Nutsubidze, 2017). The Turkish government has added implements belonging to the "Non-Contributory Regime" to its social security system in order to guarantee the rights of the elderly and individuals with disabilities to eliminate their poverty induced disadvantaged positions. In this context, the framework of the elderly and individuals with disability friendly NonContributory Regime is established with the laws No.2022 and 3294. Because of some changes made in the Individuals with Disabilities Law of 2005, in the law No.2022 the equal clauses implemented about the elderly and individuals with disabilities' monthly payments were enforced in favor of the individuals with disabilities and therefore an increase has occurred in the individuals with disabilities' pay in regard 
to the elderly payments. However, in the year 2016, the "income per capita" principle, which was implemented in favor of the elderly, was not considered for the elderly and thus created a situation contradictory with the equality principle for the individuals with disabilities. With this study, the different implementations towards the two disadvantaged social groups which are the elderly and individuals with disabilities within the Law No.2022 are discussed with a critical approach. Therefore, we aim to verify that the conditions set forth within the Law No.2022 to claim the Elderly and Individuals with Disabilities' Pay and the payment amounts are contradictory with the social justice principle. In this context, we underline that the payment practices aimed to obtain a minimum living standard aligning with the social justice system for the destitute elderly and individuals with disabilities should be designed in accordance with "per capita (net) income" principle and we make suggestions towards a solution.

\section{NON-CONTRIBUTORY SOCIAL SECURITY PRACTICES TOWARDS THE ELDERLY AND INDIVIDUALS WITH DISABILITIES THROUGH THE WORLD}

The dynamic structure of the social security systems and demographic changes have brought forward the topic of the benefits of the non-contributory systems as well as the sustainability of the contributory systems (Johnson and Williamson, 2006). In this process, because of the approach of providing a basic income for everyone, configurations were made within the non-contributory systems. So much so; in more than 85 countries the social security of the destitute elderly and individuals with disabilities is sustained through non-contributory social security implements (Filgueira and Manzi, 2017).

In general, nearly half of the people of retirement age (48\%) do not receive pensions within the contributory system. In the process of allotting an allowance to the impoverished elderly through the non-contributory system, benefits are based on income-tests, means-tests, pension-tests and citizenship, but when the social security standards of ILO are taken into account, according to the Convention No.102 and 128, one of the requirements of getting an allowance from the non-contributory system is a 20 year residency (living within the borders of said country). But in the Convention. No.131, a 15-year residency is one of the requirements to claim an allowance in old age through the non-contributory system (ILO, 2014).

In the European countries such as Netherlands, Denmark, Sweden, Norway and Finland, universal benefits are provided for the elderly based upon residency or citizenship. Contrary to that, in the United Kingdom and Ireland, Latin America and The Caribbean (Multinational State of Bolivia, Trinidad and Tobago and Mexico) and some countries in Africa (South Africa, Botswana) there seems to be and approach towards the universal or semi-universal models which are not based in noncontributory modals (Filgueira and Manzi, 2017). 
In the Asian countries, such as China, a means-tested monthly payment of 20 Dollars is made to over 65 years olds which have no social security within the contributory system based on the Minimum Living Standard Plan. In India, Social Security Pension payments are made to the elderly with the Below Poverty Card (BPL) within the scope of non-contributory payments. These payments include roughly $7-10 \%$ of the elderly population in India. The 4.5 dollars of monthly payments are at a fixed rate but can vary with the government contribution (Barrientos, 2014). For the individuals with disabilities, having a smaller share than the non-disabled individuals within full-time employment and the extra expenditure regarding disabilities with healthcare being at the top, makes the social security of individuals with disabilities a prominent concern. In this process, for preventing the probable income loss based upon a disability, non-contributory social security come into play. The full or partial benefits derived upon non-contributory system aimed for the individuals with disabilities have been implemented in 87 countries. For 60 of these countries a means-tested approach is adopted while in the other 27 universal practices prevail - noncontributory scheme is universal (Martinho, 2016). Nowadays in countries with a high welfare level, non-contributory practices for the individuals with disabilities improve rapidly (ILO, 2017).

In the European countries, such as Norway, there is a universal, joint practice to serve people within and without the workforce (Solem and Overbye, 2004). People between ages 18-67 who are permanently individuals with disabilities and thus have a 50\% diminished income because of an accident, illness and disability are qualified to have an allowance with the condition of having insurance for over three years. The income-based allowance varies between 211.073-229.588 NOK (23.81125.254 dollars) annually. The allowance in calculated through the median pension rate of the highest three year incomes of the previous five year income which were foregoing before the occurrence of the cause of the individuals with disabilities pay (Norwegian Ministry of Labor and Social Affairs, 2017: 14). In Sweden, the Disability Benefit (which was called the Disability Allowance before 2003) is a benefit financed by the public which provide a financial protection to people who have a permanent loss of work-force because of a disability, injury or illness. People who have very little or no income are being paid Guarantee Disability Benefit which is a maximum of 8.800 SEK (968 dollars) a month. The benefit is $1.4 \%$ of the Swedish GPD (Blomberg, 2013).

In the Asian countries, such as South Korea, the disability living allowance which is paid through the non-contributory payments and based upon a person's disability level varies roughly between 26 and 112 dollars (30.000-130.000 KRW). Likewise, in the year 2000, a practice has been established for the care of children with disabilities. In the year 2007 this practice has been revised as pay for children with disabilities in poverty range under the National Basic Livelihood Security Program. The amount of this benefit provided for such children varies according to the disability level between 85 and 176 dollars (100.000-200.000 KRW) monthly (Han, 2012). 
While the systems applied to each country may seem fundamentally different, the aim is to keep the destitute elderly and disadvantaged people over certain standards and ensure their livelihood. In this situation, the main problem in providing the destitute elderly and disadvantaged with benefits is to secure the sustainability regarding certain parameters. Namely it is important to evaluate criterions such as income per capita, financial capacity etc. and pay regards to the changes in these criterions (Filgueira and Manzi, 2017).

\section{THE SOCIAL SECURITY OF DESTITUTE ELDERLY AND INDIVIDUALS WITH DISABILITIES IN TURKEY}

\subsection{The Social Security of the Destitute Elderly within the Scope of Law No. 2022 and} 3294 (Elderly Pension)

The social security of the disadvantaged social groups not having social guarantee in Turkey is designed in accordance to the Non-Contributory Regime legislations. Accordingly, alongside the monthly benefits paid to the destitute elderly and individuals with disabilities within the scope of Law no. 2022, dated 01.07.1976 having the first spot, widows, and/or orphans, military families and people with children; public social benefits are periodically paid under different names within the extent of Conditional Cash Program. While the operations set forth within the Law No.2022 are operated by Social Security Institution, The General Management of Non-Contributory Payments and local finance offices; with the Statutory Decree No.633 issued in 08.06.2011 in regard to the authority granted by the Law No.6223 dated 06.04.2011, The General Management of Non-Contributory Payments has been closed down and all operations and practices under the scope of Law No.2022 has been transferred to the Ministry of Family and Social Policies to be conducted by the General Management of Social Welfare. The Law No. 22 was amended with the Statutory Decree No. 662 issued on 11.10.2011. With this amendment, the task of conducting work and operations related to the Elderly and individuals with disabilities' Benefits was transferred to Foundation of Social Contribution and Solidarity (29.05.1986 with Law No.3294). Referring to all these changes, the methods and principles regarding the performing of procedures about the Elderly and Individuals with disabilities' Benefits within the scope of Law No. 2022 has been regulated by the Code No. 28539 dated 25.01.2013.

Turkish citizens who are over 65 years of age, who were not granted alimony or unable to claim alimony, who do not receive permanent care containing boarding and lodging in public of private institutions, who do not receive allowance under the circumstances of Social Service Law No. 2828, who do not claim income or benefits from social security institutions, people who do not pay optional premiums, who do not work and be subjected to long-term insurance subsections, who has a net income less than $1 / 3$ of the minimum wage combined with said persons' and their spouses' not paying regard to residence within the same household or not (Law No.6704, dated 14.04.2016). The benefiters of Law No.2022 has been granted a monthly social income based on cash benefits principle. The benefits has 
been paid by the Pensioners' Fund quarterly every March, June, September and December, from the date of September 2018 they have started to be paid monthly (Code No. 30514 dated 19.08.2018). The Old Age Pension is paid on the amount calculated by the multiplication of the indicated amount specified in the article no. 1 of the Law No.2022 and the parameter of the civil servants' monthly pay. By the date of 01.01.2011 the destitute elderly people has been paid roughly 100 Turkish Liras (TRY), furthermore the Elderly Monthly Benefits for the year 2014 has increased to roughly 142 TRY a month. But the amount of monthly Elderly Pay has been below the individuals with disabilities pay until June 2018 . With a regulation made in June 2018, the Elderly Monthly Benefits has been increased to the amount of 500,02 TRY from 265,80 TRY. For the term of July-December 2020 the Elderly Monthly Benefits has reached to the amount of 711,50 TRY (see Table 1 ).

Table 1. The Amount of Elderly Monthly Benefits 2013-2019 by Year/Month (TRY)

\begin{tabular}{|c|c|c|c|c|c|c|c|c|}
\hline Month(s) & 2013 & 2014 & 2015 & 2016 & 2017 & 2018 & 2019 & 2020 \\
\hline January-May & 125,60 & 141,56 & 145,81 & 217,48 & 235,21 & 265,80 & \multirow{2}{*}{543,27} & \multirow{2}{*}{672,81} \\
\hline June & 125,60 & 141,56 & 145,81 & 217,48 & 235,21 & 500,02 & & \\
\hline \multirow[b]{2}{*}{ July -December } & \multirow[b]{2}{*}{130,62} & \multirow[b]{2}{*}{141,56} & \multirow[b]{2}{*}{203,44} & \multirow[b]{2}{*}{228,35} & \multirow[b]{2}{*}{251,49} & $\begin{array}{l}500,02 \\
\text { (July-August) }\end{array}$ & \multirow[b]{2}{*}{637,79} & \multirow[b]{2}{*}{711,50} \\
\hline & & & & & & $\begin{array}{l}543,27 \\
\text { (September- } \\
\text { December) }\end{array}$ & & \\
\hline
\end{tabular}

Note. Prepared by the authors with the data gathered from The Ministry of Family and Social Policies Reports 2019a; 2019b; 2019c; 2019d; 2019e; 2019f; The Ministry of Family and Social Services, 2021.

\subsection{The Social Security of Destitute Individuals with Disabilities Under the Scope of Law} No.2022

The individuals with disabilities monthly allowances granted within the Turkish public social welfare system for the individuals with disabilities with a disability rate of minimum $40 \%$, who cannot work, who cannot be employed and thus lack a stable income is the most important social security of the unemployed and destitute individuals with disabilities who remain outside the social security system.

\subsubsection{Monthly Benefits for the 40\% - 69\% Individuals with Disabilities}

The individuals with disabilities' benefits that fall into this category is the amount granted by the Foundation of Social Contribution and Solidarity to the Turkish citizens who are older than 18 and younger than 65 years of age and are determined to be individuals with disabilities by $40-69 \%$ by a fullfledged state hospital's medical board report, who were not granted alimony or unable to claim alimony, who do not receive permanent care containing boarding and lodging in public of private institutions, who do not receive allowance under the circumstances of Social Service Law No. 2828, who do not claim income or benefits from social security institutions, who has a monthly net income within the household which is less than $1 / 3$ of the minimum monthly net pay as long as the destitution continues, and calculated by the multiplication of the indicating number (3240) with the parameter of the civil servants' monthly pay (The Official Gazette No.28539, dated 25.01.2013). By the date July 2008 the 
amount of individuals with disabilities' Monthly Allowance had been determined as 166 TRY. For the years 2014/2015 this amount had been roughly 283/292 TRY monthly (see Table 2).

Table 2. The Amount of the Individuals with Disabilities' Monthly Benefits for the People Having 4069\% Disability 2013-2019 by Year/Month (TRY)

\begin{tabular}{|l|l|l|l|l|l|l|l|l|}
\hline Months & 2013 & 2014 & 2015 & 2016 & 2017 & 2018 & 2019 & 2020 \\
\hline January-June & 251,19 & 283,13 & 291,62 & 326,59 & 353,21 & 399.15 & 480,22 & 537,09 \\
\hline $\begin{array}{l}\text { July- } \\
\text { December }\end{array}$ & 261,24 & 283,13 & 305,51 & 342,92 & 377,66 & 433,68 & 509,13 & 567,97 \\
\hline
\end{tabular}

Note. Prepared by the authors with the data gathered from The Ministry of Family and Social Policies Reports 2019a; 2019b; 2019c; 2019d; 2019e; 2019f; The Ministry of Family and Social Services, 2021.

Whereas the monthly allowance of the destitute elderly who benefit from the same law was a median 142/145 TRY for the years 2014/2015 (see Table 1). The amount of the monthly benefits paid between the years 2013 and 2020 is reflected in Table 2.

\subsubsection{Monthly Benefits for People with Over 70\% Disability}

The individuals with disabilities' benefits which fall into this category is the amount granted by the Foundation of Social Contribution and Solidarity to the Turkish citizens who are older than 18, who is determined to be individuals with disabilities over $70 \%$ by a full-fledged state hospital's medical board report, who were not granted alimony or unable to claim alimony, who do not receive permanent care containing boarding and lodging in public of private institutions, who do not receive allowance under the circumstances of Social Service Law No. 2828, who do not claim income or benefits from social security institutions, who has a monthly net income within the household which is less than $1 / 3$ of the minimum monthly net pay as long as the destitution continues, and calculated by the multiplication of the indicating number (4860) with the parameter of the civil servants' monthly pay (The Official Gazette No.28539, dated 25.01.2013). By the date of July 2008, the amount of Monthly Allowance for People Having an Over 70\% Disability is determined to be 249 TRY. For the first six months of the years 2014/2015 this amount had been 425/437 monthly. The amount of Monthly Pay has increased to a median of 852 TRY. By the July-December term (see Table 3).

Table 3. The Amount of the Individuals with Disabilities' Monthly Benefits for the People Having an Over 70\% Disability 2013-2019 by Year/Month (TRY)

\begin{tabular}{|l|l|l|l|l|l|l|l|l|}
\hline Months & 2013 & 2014 & 2015 & 2016 & 2017 & 2018 & 2019 & 2020 \\
\hline January-June & 376,79 & 424,69 & 437,44 & 489,88 & 529,82 & 598,72 & 720,33 & 805,62 \\
\hline July-December & 391,86 & 391,86 & 458,26 & 514,38 & 566,49 & 650,52 & 763,69 & 851,95 \\
\hline
\end{tabular}

Note. Prepared by the authors with the data gathered from The Ministry of Family and Social Policies Reports 2019a; 2019b; 2019c; 2019d; 2019e; 2019f; The Ministry of Family and Social Services, 2021.

\subsubsection{Monthly Allowance for Relatives of an Individual with Disabilities Who is the Under}

\section{Years of Age}

Monthly Allowance for the relatives of an individual with disabilities under 18 years old is the amount granted by the Foundation of Social Contribution and Solidarity to the Turkish citizens with the 
condition of cohabiting, who undertake the physical care of their relatives who are younger than 18 years of age and determined to be individuals with disabilities by at least $40 \%$ by a full-fledged state hospital's medical board report, who were not granted alimony or unable to claim alimony, who do not receive permanent care containing boarding and lodging in public of private institutions, who do not receive allowance under the circumstances of Social Service Law No. 2828, who do not claim income or benefits from social security institutions, who has a monthly net income within the household which is less than $1 / 3$ of the minimum monthly net pay as long as the destitution continues, and calculated by the multiplication of the indicating number (3240) with the parameter of the civil servants' monthly pay (The Official Gazette No.28539, dated 25.01.2013). By the date of July 2008, the amount of Monthly Allowance for the Relatives of Individuals with Disabilities under 18 years of age is determined to be 166 TRY. For the first six months of the years 2014/2015 this amount had increased to 283/292 monthly. The Monthly Allowance for the Relatives of Individuals with Disabilities under 18 years of age for the year 2020 has been determined to be 537 TRY for the January- June term and 567 TRY for the JulyDecember (see Table 4).

Table 4. The Amount of the Monthly Allowance for the Relatives of Individuals with Disabilities under 18 years of age 2013-2019 by Year/Month (TRY)

\begin{tabular}{|l|l|l|l|l|l|l|l|l|}
\hline Months & 2013 & 2014 & 2015 & 2016 & 2017 & 2018 & 2019 & 2020 \\
\hline January-June & 251,19 & 283,13 & 291,62 & 326,59 & 353,21 & 399.15 & 480,22 & 537,09 \\
\hline $\begin{array}{l}\text { July- } \\
\text { December }\end{array}$ & 261,24 & 283,13 & 305,51 & 342,92 & 377,66 & 433,68 & 509,13 & 567,97 \\
\hline
\end{tabular}

Note. Prepared by the authors with the data gathered from The Ministry of Family and Social Policies Reports 2019a; 2019b; 2019c; 2019d; 2019e; 2019f; The Ministry of Family and Social Services, 2021.

As one can see, the amount of Monthly Benefits for the People Having a 40\% - 69\% Disability and mount of Monthly Allowance for the Relatives of individuals with disabilities under 18 years of age had always been in close approximate through the years.

\section{A CRITICAL APPROACH TOWARDS THE DIVERGENT PAYMENT TYPES AND AMOUNTS WITHIN THE ELDERLY AND RELATIVES OF INDIVIDUALS’ WITH DISABILITIES PAY}

\subsection{The 1976-2005 Term}

With the first implementations, the elderly and Relatives of individuals with disabilities who have an income under a certain amount (the poverty line) and thus are beneficiaries under the Law No.2022 had been granted monthly benefits on the basis of cash benefits. The elderly, individuals with disabilities and the relatives of the individuals with disabilities' allowances had been calculated by the multiplication of the indicating number (1.620) with the parameter of the civil servants' monthly pay. Namely the basic social needs had been met, in spite of that there had not been a significant contribution to establishing the social justice and the amount of the individuals with disabilities' allowance have always been around the same level as per the principle of equality until the year 2005 (Seyyar, 2015). 


\subsection{The 2005-2016 Term}

With the Individuals with Disabilities' Law of 2005, it has been decided for the monthly allowance amounts set forth within Law No.2022 to be established as per the elderly pensions. However, after the calculation of the Elderly Pensions (elderly allowance) as per the indicating number of 1.620, "the monthly allowances of people with a $40 \%$ - 69\% disability and relatives of an individual with disabilities under the age of 18 " has been set forth as $200 \%$ of the amount calculated with the indicating number, and the monthly allowances of people with over $70 \%$ disability has been determined as $300 \%$ of the amount calculated with the indicating number. Namely even though the indicating number had been the same, people with $40-69 \%$ disability and relatives of an individual with disabilities under the age of 18 had started to obtain benefits double the amount of elderly peoples' pay and people with over $70 \%$ disability had started to obtain benefits triple the amount of elderly peoples' pay (Seyyar, 2015). Even though the elderly and individuals with disabilities within the scope of The Law and therefore it is officially accepted as part of the social groups with disabilities and thus destitute, it could be acceptable for the individuals with disabilities to claim benefits double the amount of the elderly depending on their level of disability because of their additional social needs. But implementing variant amounts of public social welfare practices between the destitute and thus disadvantaged social groups is against the principle of social justice. With the regulations made within the year 2013 the principle of setting forth the individuals with disabilities' monthly allowances upon the elderly pensions has been annulled on favor of the individuals with disabilities and a dual system has been adopted. Instead of this, new indicating numbers have been generated for every type of monthly allowances as it is written below (Law No.6495 dated 12.07.2013):

Elderly Peoples’ Allowance: 1.620.

Monthly Allowance;

for People with 40\% - 69\% Disability: 3.240.

for People Over 70\% Disability: 4.860.

Monthly Allowance for the Relatives of Individuals with Disabilities Minor: 3.240.

The new monthly allowance amounts established in accordance with the Law No.2022 has been set forth upon these indicating numbers determined for every type of benefits. Within the scope of the aforementioned Law the poverty threshold has been reset by re-establishing the minimum wage and parameter of the civil servants' monthly pay of the second half of the year; and 1/3 of the minimum wage has been increased to the amount of 243,43 TRY for the 01.07.2013 - 31.12.2013 term (Law No. 6495 dated 12.07.2013). While the household poverty threshold had always been updated every six months and implemented accordingly, from the year 2016 and on it has started to be updated annually. 
The household poverty thresholds from the second part of the year 2012 to the year 2020 is shown below in Table 5.

Table 5. Household Poverty Threshold (2012-2019) (TRY)

\begin{tabular}{|l|l|l|}
\hline Year & Time Period & $\begin{array}{l}\text { Household Poverty } \\
\text { Threshold (TRY) }\end{array}$ \\
\hline 2012 & January-December & 119,62 \\
\hline 2013 & $\begin{array}{l}\text { January-June } \\
\text { July-December }\end{array}$ & $\begin{array}{l}124,40 \\
243,43\end{array}$ \\
\hline \multirow{2}{*}{2014} & January-June & 255,22 \\
& July-December & 270,23 \\
\hline \multirow{2}{*}{2015} & January-June & 286,32 \\
& July-December & 303,48 \\
\hline 2016 & January-December & 392,49 \\
\hline 2017 & January-December & 423,58 \\
\hline 2019 & January-December & 483,64 \\
\hline 2020 & January-December & 609,67 \\
\hline
\end{tabular}

Note. Calculated and compiled by the authors with the data obtained from The Ministry of Family and Social Policies Reports, 2019a; The Ministry of Family and Social Services, 2021, 1/3 amount of the minimum net wage (excluding the subsistence allowance).

There is a provision that states "The social reviews of the people who has been granted an allowance are done annually" in the Code No.28539 dated 25.01.2013 and the principles and practices regarding the elderly/ individuals with disabilities' allowance provided as per the Law No.2022. In accordance with this provision the social reviews of existing benefiters is made/renewed and it is being checked if they can still claim benefits by the government.

The provision regarding the allowance for the care of the individuals with disabilities being added to the personal income is written as such (Law No.28952 dated 25.03.2014): "Excluding the allowances granted as per the Law No.2022, the monthly median of the social benefits being granted is taken into account including the home-care payments article Annex. 7 of the Social Services Law No.2828, dated 24.05.1983, conditional educational benefits obtained perpetually and regularly, conditional healthcare benefits, benefits aimed at female widows, scholarships, allowances." According to this it is probable for some of the individuals with disabilities who obtain benefits both Individuals with Disabilities Allowance from Law No.2022 and home-care allowance to lose their Individuals with Disabilities Allowance.

\subsection{The Post-2016 Era}

With a new legislation made in 2016, while the other conditions for claiming Monthly Allowance remains unchanged, it is established to calculate the "income per capita" by taking into account the said persons' and their spouses' incomes, not the household for claiming for the Elderly Monthly Allowance (Law No.6704 dated 14.04.2016). As per this law amendment during the granting of an Elderly Allowance, only "the elderly person's personal and spousal income" will be taken into 
account for the destitution criteria. In other words, whether the elderly person has relatives or not, the incomes of other people living in the same household will not be taken into account.

If an elderly person who receives Elderly Allowance in the present state wishes to swap into the individuals with disabilities' category and proves his/her disability with a full-fledged state hospital's medical board report, the disability level written in the medical board report should be over $70 \%$. A disability level of $40-69 \%$ is not enough to swap into the Individuals with Disabilities' Allowance category. Only the citizens who obtain a medical board report who are over the age of 65 and have a disability level of between $40 \%$ and $69 \%$ could be granted The Elderly Monthly Allowance. In the instance of a citizen who already receive elderly allowance wishing to swap into the Individuals with Disabilities' Allowance category with a full-fledged state hospital's medical board report showing at least $70 \%$ disability, the assessment of destitution is made with the household income approach. Namely in this situation, the calculation is based on "every household member's income" instead of the "personal and spousal income".

With only taking into account the claimant elderly peoples' and their spouse's income and not regarding the incomes of their other relatives, the conditions for claiming the Elderly Monthly Allowance has become easier than claiming Individuals With Disabilities' Allowance. To give an example: a widowed citizen who has no assets or stable income registry resides in the house of his child who also has a child (his grandchild). His child and daughter in law who reside in their own house do not pay rent and a combined monthly income of 12.000 TRY. Considering this example, if the household income based approach, which was annulled in 2016, was taken as a basis, the elderly person living in this well-off household would not be able to claim monthly benefits. But with these changing conditions the even though the elderly citizen lives in a well-off household, he can Elderly Persons' Allowance perpetually. Furthermore, if there have been a citizen with disabilities with the same conditions in place of the elderly citizen; the individuals with disabilities would have not claimed benefits because the household median income is over the household destitute threshold. Thereby, two disadvantaged people within the scope of the same Law has faced an injustice based on complicated and different practices which are mostly hard to explain logically. In a clearer expression; the Allowances granted to the destitute elderly have always been less than the Individuals with Disabilities' Allowances. But only after June 2018 the amount of The Elderly Persons' Allowances has increased to over between 40-69\% Disability Allowances and Allowances for the Individuals with Disabilities Minors (see Table 6).

Table 6. The Amount of Elderly and Individuals with Disabilities' Pay Comparatively (2013-2019)

\begin{tabular}{|l|l|l|l|}
\hline Year: Months & $\begin{array}{l}\text { Allowance for } \\
\text { People Over 65 } \\
\text { Years of Age } \\
\text { (Median/TRY) }\end{array}$ & $\begin{array}{l}\text { Allowance for People } \\
\text { with 40-69\% Disability } \\
\text { Allowance for Relatives } \\
\text { of a Disabled Minor } \\
\text { (TRY) }\end{array}$ & $\begin{array}{l}\text { Allowance } \\
\text { People with 70\% } \\
\text { Disability } \\
\text { (TRY) }\end{array}$ \\
\hline 2013: January-June/ July-December & $125 / 130$ & $251 / 261$ & $376 / 391$ \\
\hline 2014: January-June/ July-December & $142 / 142$ & $283,13 / 283,13$ & $392 / 392$ \\
\hline
\end{tabular}




\begin{tabular}{|l|l|l|l|}
\hline 2015: January-June/ July-December & $146 / 203$ & $292 / 306$ & $437 / 458$ \\
\hline 2016: January-June/ July-December & $217 / 228$ & $326 / 342$ & $489 / 514$ \\
\hline 2017: January-June/ July-December & $235 / 251$ & $353 / 377$ & $529 / 566$ \\
\hline $\begin{array}{l}\text { 2018: January - May/ June - August/ } \\
\text { September - December }\end{array}$ & $265 / 500 / 543$ & $399 / 433$ & $598 / 650$ \\
\hline 2019: January-June/ July-December & $543 / 637$ & $480 / 509$ & $720 / 763$ \\
\hline 2020: January-June/ July-December & $673 / 712$ & $537 / 568$ & $806 / 852$ \\
\hline
\end{tabular}

Note. Prepared by the authors with the data gathered from The Ministry of Family and Social Policies Reports 2019a; 2019b; 2019c; 2019d; 2019e; 2019f; The Ministry of Family and Social Services, 2021.

On the other hand, as shown in the example, after the year 2016 it has become harder for the individuals with disabilities to claim benefits than the elderly persons even though they possess the same conditions.

\section{THE DEMOGRAPHIC CONDITION OF THE ELDERLY AND INDIVIDUALS WITH DISABILITIES WITHIN THE NON-CONTRIBUTORY PRACTICES IN TURKEY}

In the context of data gathered from Turkish Statistical Institute Elderly and Individuals with Disabilities Research, the elderly population was 5.9 million people in 2013, has increased to 7.1 million people by the year 2018. According to the 2018 data, $8.8 \%$ of the total population is comprised of elderly individuals. The amount of the elderly people has increased to 709.590 from 632.407 between the years 2013 and 2018 (see Table 7).

According to the November 2019 journal of The Ministry of Family, Labor and Social Services, the population of people over 65 years old who receive elderly persons' pension through the noncontributory system has increased to 795.925 (The Ministry of Family, Labor and Social Services 2019, 1; Turkish Statistical Institute 2019a,1; Turkish Statistical Institute, 2019b: 1).

According to the National Individuals with Disabilities Database, the amount of individuals with disabilities in Turkey in the year 2018 is 1.6 million people (Association for Living Without Obstacles, 2019) According to the Turkish Statistical Institute Individuals with Disabilities' Research Report dated 2002 , the individuals with disabilities is roughly 12,9\% of the total population. In accordance with the Law No. 2022; while for claiming monthly allowance for the relatives of an individuals with disabilities minor a 40\% and over disability is enough, in the situation of people between 18-65 years of age there are two different outcomes for having 40-69\% and over 70\% disability. In this aspect, regarding the numbers of total individuals with disabilities', people having a less than $40 \%$ percent disability should also be taken into account. But in operation, even though a person not having an eye is regarded as an individual with disabilities, for this person having a 30\% disability prevents him from claiming benefits / early retirement / tax advantages. While Turkish Statistical Institute has not released new data regarding the amount of individuals with disabilities since the year 2011, the unofficial disability rate has been declared as 12.9\%. Conditions such as speaking quickly, not having eyesight in one eye, stuttering, nasal speech, being cross-eyed etc. are included in this $12.9 \%$. In this study, the data regarding the total disabilities are calculated Turkish Statistical Institute by the centerline of the official data released with the Elderly and Individuals with Disabilities' Statistical Journal of MFLSS (Turkish Statistical Institute, 2019a: 1; Turkish Statistical Institute, 2019b: 1). 
Table 7. The Total Elderly and Individuals with Disabilities/Annual Allowance for Destitute Individuals with Disabilities and Destitute Elderly (2013-2018)

\begin{tabular}{|l|l|l|l|l|l|l|}
\cline { 2 - 7 } \multicolumn{1}{c|}{} & 2013 & 2014 & 2015 & 2016 & 2017 & 2018 \\
\hline The Percentage of Elderly Population & $7,7 \%$ & $8 \%$ & $8,2 \%$ & $8,3 \%$ & $8,5 \%$ & $8,8 \%$ \\
\hline $\begin{array}{l}\text { The Percentage of Individuals with } \\
\text { Disabilities }\end{array}$ & $1,61 \%$ & $1,78 \%$ & $1,85 \%$ & $1,92 \%$ & $2 \%$ & $2,04 \%$ \\
\hline Total Elderly Population (1.000 People) & 5.892 & 6.193 & 6.495 & 6.651 & 6.895 & 7.163 \\
\hline $\begin{array}{l}\text { Total Individuals with Disabilities (1.000 } \\
\text { People) }\end{array}$ & 1.235 & 1.386 & 1.454 & 1.529 & 1.615 & 1.671 \\
\hline $\begin{array}{l}\text { The Elderly Population that get 65+ Age } \\
\text { Destitute Elderly Pay (People) }\end{array}$ & 632.407 & 629.590 & 608.513 & 620.019 & 618.162 & 709.590 \\
\hline $\begin{array}{l}\text { The Amount of Expenses Made for The } \\
\text { Benefiters (of 65+ Age Pay Million TRY) }\end{array}$ & 1.009 & 1.009 & 1.250 & 1.580 & 1.766 & 2.900 \\
\hline The Destitute Elderly (People) & 590.144 & 687.554 & 708.507 & 715.245 & 714.662 & 722.554 \\
\hline $\begin{array}{l}\text { The Amount of Expenses Made for The } \\
\text { Benefiters of Individuals with Disabilities } \\
\text { Pay (Million TRY) }\end{array}$ & 2.314 & 2.590 & 2.806 & 3.182 & 3.513 & 3.367 \\
\hline
\end{tabular}

Note. The calculations were made by the authors with the data gathered from Turkish Statistical Institute 2019a; Turkish Statistical Institute, 2019b; The Ministry of Family and Social Policies Reports 2019a; 2019b; 2019c; 2019d; 2019e; 2019f.

While $1.61 \%$ of the total population were individuals with disabilities in the year 2013, in the year 2018 this rate went up to $2.04 \%$. Besides this increase, there has also been an increase in the amount of the destitute elderly. While the amount of destitute elderly people had been 590.144 in the year 2013, in 2018 it has reached to 722.554 (see Table 7).

The increase in the amount of elderly and individuals with disabilities also causes a rise in the amount of expenses made for the destitute elderly and individuals with disabilities receiving Monthly Payments through the non-contributory systems. So much so, the amount of payments made to the elderly through the non-contributory system has increased three-fold between the years 2013-2018. Through the same process, the expenses made for the individuals with disabilities has generally increased (even though not as fast-risen as the expenses made for the elderly).

With the current demographic tendencies, it is expected for the individuals with disabilities' population to comprise $2.46 \%$ of the total population, to have over 725 thousand destitute individuals with disabilities and over 750 thousand destitute elderly people by the year 2023 (The Ministry of Family, Labor and Social Services 2019,1$)$. The $1.1 \%$ rise in the amount of elderly people and $0.43 \%$ in the amount of individuals with disabilities observed in the roughly 5 year period between the years 2013-2018 backs up this expectation.

\section{THE INCOME PER CAPITA PRINCIPLE IN DETERMINING THE ELDERLY AND INDIVIDUALS WITH DISABILITIES PAY}

When the systematic payments made to the individuals with disabilities and elderly through the non-contributory system is taken into account, it is observed that most payments are made in monthly intervals, poverty tests etc. are considered for granting monthly allowances and in the matter of elderly 
payments, practices that are based on the individual himself, not the whole household are adopted more frequently. In spite of that, the amount of elderly and individuals with disabilities' monthly allowances within the non-contributory system is still an important problem for saving the individuals from a state of destitution.

Furthermore, it is an important economic and social right for the citizens to live especially without staying below the hunger threshold and sustain their economic and social needs in the country's conditions. Within the scope of this, it is essential to have a calculation beyond the effect factor of the household income or personal income being used to determine the poverty threshold when the monthly allowances of the destitute individuals with disabilities and elderly persons are being designated. Under these circumstances what needs to be done is to use the net income per capita for the calculations of the Monthly Allowances whether the destitute person is elderly or individuals with disabilities. Namely, it is much more fair approach to ensure that the monthly allowances paid to the destitute elderly and individuals with disabilities to move them away from the hunger threshold and closer to the minimum wage. This approach carries further importance to ensure the social justice which is one of the important purposes of social security (Ramparakash, 1994: 118).

To make an assessment about Turkey in this regard, the most reasonable solution to keep the destitute elderly and individuals with disabilities above the hunger threshold is to designate the individuals with disabilities and destitute persons' (who are within the scope of Law No. 2022) monthly income level as $1 / 12$ th of the $40 \%$ of the national income per capita. The $40 \%$ rate recommended here could be re-determined as per the economic and social terms of the country. Nonetheless, this rate should not reduce the monthly income of the destitute, individuals with disabilities and elderly persons' below the hunger threshold (2.124 TRY for Turkey). This practice calculated below through the example of Turkey could be implemented as per every country's own terms (national income, national income per capita etc.).

\section{AN ASSESSMENT TOWARDS THE REFORMATION OF THE MONTHLY ALLOWANCES OF DISADVANTAGED ELDERLY AND INDIVIDUALS WITH DISABILITIES PERSONS'}

The rapidly rising number of elderly and individuals with disabilities within the increasing population of Turkey and the amounts of monthly allowances paid to the elderly and individuals with disabilities', which also has a rapidly increasing number, staying below the minimum living standard constitutes a significant problem as per the social justice principle.

However according to the calculations made for people to sustain their livelihoods without staying below the minimum living standard; it could be seen that the poor elderly and individuals with disabilities in Turkey receive inadequate monthly payments even though regulations have been made. So much so that as per the income per capita principle which could be described as at least $40 \%$ of the 
median income per capita, the monthly allowances paid to the elderly and individuals with disabilities through the non-contributory system is inadequate. Even though the payments to the elderly people are made based on personal income, not the household income, or even though the amount of the monthly payments made to the individuals with disabilities exceeded the allowances of the elderly for a while, the monthly allowances of the elderly and individuals with disabilities' is still a problematic area. Actually, one dimension of this matter is keeping the monthly payments made to both of these group in close proximity. Above this, the subject that essentially need to be emphasized is how the payments of these two groups will be made in accordance with social justice.

When Table 8 is evaluated for 2018, the non-contributory payments in 2018, we observe that: a) elderly individuals have received an annual payment of 5,470.56 TRY total, b) an individual with disabilities with 40-69\% level of disability has received an annual payment of 4,996.68 TRY, and c) an individual with disabilities with $70 \%$ and above level of disability has received an annual payment of 7,495.44 TRY (see Table 8). In this time period, the income per capita for the year of 2018 is $50,878.00$ TRY.

Table 8. Elderly and Annual Payments for Destitute Individuals with Disabilities and Destitute Elderly (Monthly Allowances, Median Income Per Capita (2013-2019)

\begin{tabular}{|c|c|c|c|c|}
\hline Years & $\begin{array}{l}\text { Median Annual Income } \\
\text { Per Capita } \\
\text { (\$/TRY) }\end{array}$ & $\begin{array}{l}\text { Pay for People of } 65 \\
\text { Years of Age and } \\
\text { Over } \\
\text { (TRY/Year) }\end{array}$ & $\begin{array}{l}\text { Individuals with } \\
\text { Disabilities', } \\
\text { Monthly Pay } \\
(40-69 \%) \\
\text { (TRY/Year) }\end{array}$ & $\begin{array}{l}\text { Individuals with } \\
\text { Disabilities' } \\
\text { Monthly Pay } \\
\text { (70\% and over) } \\
\text { (TRY/Year) }\end{array}$ \\
\hline 2013 & $\$ 12.519 / 23.786$ TRY & $1.537,32$ & $3.074,58$ & $4.611,90$ \\
\hline 2014 & $\$ 12.095$ / 26.367 TRY & $1.698,72$ & $3.397,56$ & $4.899,30$ \\
\hline 2015 & $\$ 10.948$ / 29.778 TRY & $2.095,50$ & $3.582,78$ & $5.374,20$ \\
\hline 2016 & $\$ 10.820 / 32.460 \mathrm{TRY}$ & $2.674,98$ & $4.017,06$ & $6.025,56$ \\
\hline 2017 & 10.513 / 38.162 TRY & $2.920,20$ & $4.385,22$ & $6.577,86$ \\
\hline 2018 & $\$ 9.370$ / $50.878 \mathrm{TRY}$ & $5.470,56$ & $4.996,68$ & $7.495,44$ \\
\hline 2019 & \$9.127 / 54.312 TRY & $7.086,36$ & $5.936,10$ & $8.904,12$ \\
\hline 2020 & $\$ 8.538$ / 63.460 TRY & $8.305,86$ & $6.630,36$ & $9.945,42$ \\
\hline
\end{tabular}

Note. Organized by the authors with the data gathered from Central Bank of the Republic of Turkey, 2020; The Ministry of Family, Labor and Social Services 2019; Ministry of Family and Social Services 2021; Statista, 2020; World Bank, 2020.

When these data are taken into account and a calculation is made as per the income per capita principle; the $40 \%$ of the income per capita for the year 2018 is $20.351,20$ TRY. This sum equals to the minimum amount for a person to sustain his life without staying below a certain level. According to this, the amount that needs to be paid to an elderly individual (who had been receiving monthly payments 
through the non-contributory system) to cover the difference for obtaining a total annual income of 20.351,20 TRY is 14.880,64 TRY. When we take into account the same payment difference for the individuals with disabilities, the difference that needs to be paid to a person with $40-69 \%$ level of disability is $15.354,52 \mathrm{TRY}$. The difference that needs to be paid to a person with $70 \%$ and above level of disability is $12.885,76$ TRY (see Table 9). When we consider that the payments were made with monthly intervals, the difference needs to be paid divided into months as well.

Table 9. The Monthly Allowances Which Should be Paid to The Elderly and Individuals with Disabilities as Per the Income Per Capita Principle and the Difference Amount (TRY) (2013-2019)

\begin{tabular}{|l|l|l|l|l|}
\hline Years & $\begin{array}{l}\text { Net Income Per } \\
\text { Capita x 0.40 } \\
\text { (TRY /Year) }\end{array}$ & $\begin{array}{l}\text { Difference with the } \\
\text { Mont. Pay of Ppl. } \\
\text { Over 65 } \\
\text { (TRY /Year) }\end{array}$ & $\begin{array}{l}\text { Difference w. } \\
\text { Individuals with } \\
\text { Disabilities' Pay } \\
(40-69 \%) \\
\text { (TRY/Year) }\end{array}$ & $\begin{array}{l}\text { Difference w. } \\
\text { Individuals with } \\
\text { Disabilities' Pay } \\
\text { (70\% and Over }) \\
\text { (TRY/Year) }\end{array}$ \\
\hline 2013 & $9.514,40$ & $7.977,08$ & $6.439,82$ & $4.902,50$ \\
\hline 2014 & $10.546,80$ & $8.848,08$ & $7.149,24$ & $5.647,50$ \\
\hline 2015 & $11.911,20$ & $9.815,70$ & $8.328,42$ & $6.537,00$ \\
\hline 2016 & $12.984,00$ & $10.309,02$ & $8.966,94$ & $6.958,44$ \\
\hline 2017 & $15.264,80$ & $12.344,60$ & $10.879,58$ & $8.686,94$ \\
\hline 2018 & $20.351,20$ & $14.880,64$ & $15.354,52$ & $12.855,76$ \\
\hline 2019 & $21.724,80$ & $14.638,44$ & $15.788,7$ & $12.820,68$ \\
\hline 2020 & $25.384,00$ & $17.078,14$ & $18.753,64$ & $15.438,58$ \\
\hline
\end{tabular}

Note. Organized by the authors with the data gathered from Ministry of Family, Labor and Social Services, 2019; Ministry of Family and Social Services, 2021; World Bank, 2020.

\section{CONCLUSION}

Based on the approach of providing a basic income for everyone, the developing countries and under-developed countries have started to build structures on the non-contributory systems just as much as the well-developed countries. In this process, from the well-developed European countries to the developing Asian countries, nearly every country's non-contributory system practices had improvements for the destitute individuals with disabilities and elderly people under different names and criteria.

In Turkey, lots of changes have been made for the practices regarding public social aid towards the poor elderly and individuals with disabilities since the year 1976 with the Law No.2022. Implementing different practices towards two disadvantaged social groups which are under the same destitute conditions specified within the same law is not compatible with the public equality and social justice principles. The Law, which has come into force for the last time in 26.04.2016, has differentiated the calculations to determine the elderly persons' destitution conditions from the individuals with disabilities'. According to this, the destitution calculations for an elderly person who is 65 years old and over have been based only on his income and spousal income (if the spouse has any). However, for the calculations of individuals with disabilities' a larger social circle has been taken into account and thus the household approach has continued. This differential implementation could naturally be regarded as 
a double standard in favor of the elderly. But the allowances of the elderly have always been below the Individuals with Disabilities Allowances until June 2018.

The right way is to have all disadvantaged social groups under the scope of non-contributory practices be subjected to the same destitution criteria and thus receiving equal amounts of public social benefits. The government shouldn't settle with this and the "Median Income Per Capita" principle should be accepted regarding all Monthly Allowances paid within Public Social Aid to enhance the minimum living standards of disadvantaged social groups. By granting the Monthly Allowances in accordance with this principle, the fundamentals of public fairness and social justice will be implemented. As for this principle, the essentials for sustaining an income which is on par with human dignity for a disadvantaged person will be determined by the indexation of the general economic power of every country. In this sense, the amount of Monthly Allowances which is the monetary extent of the minimum living standards (Public Social Aid) keeping the individuals above the hunger threshold, are determined as $40 \%$ to $60 \%$ of the median income per capita of a country on a yearly basis.

In this context, the $40 \%$ of the median income per capita will provide the elderly and individuals with disabilities within the non-contributory system a minimum living standard. In Turkey where the hunger threshold is around 2.124 TRY and the net minimum wage is 2.020,90,70 TRY by the year 2019, an assessment should be made as at least $40 \%$ of the median income per capita for the monthly allowances paid to the individuals with disabilities and elderly individuals within the non-contributory system. Besides, "The Household Hunger Threshold" should be renounced and in place of this the "Income Per Capita" principle should be implemented; the conditions to grant benefits to the individuals with disabilities and elderly people through the non-contributory system should be as close to each other as possible. Thereby the monthly incomes of all individuals belonging to disadvantaged social categories will be on an equal level and the median welfare level of other income groups will be caught up on an important degree and the goal of social justice will be obtained.

The effects of the Covid-19 pandemic on health, which have influenced the world since December 2020, have created significant pressures on economic and social life in a short time. Especially in the field of social benefits, the governments are directed to look for new social protection prescriptions for those who were in needy positions before the process and for those who have become unemployed due to the effects of the pandemic. This situation poses a significant problem for the social security system and funds of Turkey. The effects of the pandemic have the potential to create serious pressures on disability and elderly payments in the near future in Turkey.

\section{REFERENCES}

Association for Living without Obstacles (2019). Disability in the World and Turkey with Numbers. https://ey-der.com/ana-sayfa/turkiye-ve-dunyada-engelliler/ [accessed: 10.12.2019]. 
Authority Regarding the Organizations, Duties and Powers of Public Institutions and Organizations and Public Officials to Ensure That the Public Services are Executed Regularly, Effectively and Efficiently Act of 6223. (2011). https://www.resmigazete.gov.tr/eskiler/ 2011/05/20110503-1.htm [accessed: 10.12.2019].

Aysoy, M. (2004). Disability Policy in the European Union Process. Istanbul: Açı Books.

Barrientos, A. (2014). Is there a role for social pensions in Asia?. Asia \& the pacific policy studies, 2 (1), 8-20. doi:10.1002/app5.63.

Blomberg, R. (2013). Who is granted disability benefit in sweden? Description of risk factors and the effect of the 2008 law reform. Royal Institute of Technology School of Engineering Sciences Master of Science Thesis, Stockholm, Sweden.

Central Bank of the Republic of Turkey. 2020. Exchange rates. https://www.tcmb.gov.tr/ kurlar/kurlar_tr.html [accessed: 01.03.2020].

Decision Amending Some Laws and Decree Law (Omnibus Bill) Act of 6495 (2013). https://www.resmigazete.gov.tr/eskiler/2013/08/20130802-1.htm [accessed: 1003.2020].

Decree Law on the Organization and Duties of The Ministry of Family and Social Policies Act of 633 (2011). https://www.resmigazete.gov.tr/eskiler/2011/06/20110608M1-1..pdf [accessed: 15.04.2020].

East Marmara Development Agency (2011). Increasing the Employment Potential of Disadvantaged Groups in Dilovasi: Research Results Report. East Marmara Development Agency, Kocaeli-Turkey: Marka Publications.

Filgueira, F. \& Pilar, M. (2017). Pension and income transfers for old age inter-and intra generational distribution in comparative perspective. United Nations, Social Policy Series, ISSN 1680-8983.

Granting Pensions to Destitute, weak and helpless Turkish 65 Years and Older Citizens Act of 2022 (1976). https://www.mevzuat.gov.tr/MevzuatMetin/1.5.2022.pdf [accessed: 22.03.2020).

Granting Pensions to Destitute, Weak and Helpless Turkish 65 Years and Older Citizens and Amending Some Laws and Decree Laws Act of 6704 (2016). https://www.resmigazete.gov.tr/eskiler/2016/04/20160426-11.htm [accessed: 10.12.2019].

Granting Pensions to Destitute, Weak and Helpless Turkish 65 Years and Older Citizens and Amending Regulation on The Regulation of 30514 (2018). https://www.resmigazete.gov.tr/eskiler/2018/08/20180819-2.pdf [accessed: 20.12.2019].

Granting Pensions to Destitute, Weak and Helpless Turkish 65 Years and Older Citizens Regulation of 28539. (2013). https://www.resmigazete.gov.tr/eskiler/ 2013/01/2013012523.htm [accessed: 20.12.2019].

Granting Pensions to Destitute, Weak and Helpless Turkish 65 Years and Older Citizens and Amending Regulation on the Regulation of 28952 (2014). https://www.resmigazete.gov.tr/ eskiler/2014/03/20140325-1.htm [accessed: 25.12.2019].

Han, S. (2012). Republic of Korea: Updating and improving the social protection index. Technical Assistance Consultant's Report, Project Number: 44152 Regional Capacity Development Technical Assistance (R-CDTA), Asia Development Bank. 
ILO (2017). World Social Protection Report 2017-19 Universal Social Protection to Achieve The Sustainable Development Goal, Geneva.

ILO (2019). Social Protection for Older Persons: Key Policy Trends and Statistics. https://www.ilo.org/wcmsp5/groups/public/---dgreports/-

dcomm/documents/publication/ wcms_310211.pdf [accessed: 10.12.2019].

Johnson, J.K.M. \& Williamson, J.B. (2006). Do universal non-contributory old-age pensions make sense for rural areas in low-income countries?. International Social Security Review, 59 (4), 47-65.

Martinho, M. (2016). Social Protection for Persons with Disabilities. Expert Group Meeting 'Promoting Inclusion Through Social Protection' Report on the World Social Situation 2017, New York, 1-2 December 2016.

Mayer, E. S. (2003). What is a disadvantaged group?. Effective Communities Project. Minneapolis, USA.

Norwegian Ministry of Labor and Social Affairs (2017). The Norwegian Social Insurance Scheme, Norway: Published by Norwegian Ministry of Labor and Social Affairs.

Nutsubidze, T. \& Nutsubidze, K. (2017). The challenge of pension reform in Georgia: Noncontributory pensions. International Social Security Review, 70(1), 79-108.

Ramparakash, D. (1994). Poverty In The countries of the European Union-A synthesis of Eurostat's research on property. Journal of European Social Policy, 4(2), 117-128.

SEYYAR, A. (2015). Disabled-friendly social policy in the world and turkey. Istanbul: Ragbet Publications.

Social services act of 2828 (1983). https://www.mevzuat.gov.tr/MevzuatMetin/1.5.2828.pdf [accessed: 10.12.2020].

Solem, P. E. \& Overbye, E. (2004). Norway: Still High Employment Among Older Workers. Ed. Tony Maltby, Bert De Vroom, Maria Luisa Mirabile, Einar Overbye, Ageing and the Transition to Retirement A Comparative Analysis of European Welfare States, London and New York: Routledge.

Statista (2020). Turkey: Gross Domestic Product (GDP) Per Capita in Current Prices from 1984 to 2024. https://www.statista.com/statistics/263599/gross-domestic-product-gdpper-capita-in-turkey/ [accessed: 10.12.2020].

The Ministry of Family and Social Policies (2019a). Ministry of Family and Social Policies; Statistical Information About Disabled Individual General Directorate of Disabled and Elderly Services. http://sgb.aile.gov.tr/argeraporlar/bakanlik-faaliyet-raporlari [accessed: 15.12.2019].

The Ministry of Family and Social Policies (2019). Annual Report 2016-Ministry of Family and Social Policies. https://www.ailevecalisma.gov.tr/Uploads/sgb/uploads/pages/argeraporlar/2016-yili-faaliyetraporu.pdf [accessed: 15.12.2019].

The Ministry of Family and Social Policies (2019c). Annual Report 2015-Ministry of Family and Social Policies. https://www.ailevecalisma.gov.tr/Uploads/sgb/uploads/pages/arge-raporlar/2015-yiliidare-faaliyet-raporu.pdf [accessed: 15.12.2019].

The Ministry of Family and Social Policies (2019d). Annual Report 2014-Ministry of Family and Social Policies. https://www.ailevecalisma.gov.tr/Uploads/sgb/uploads/pages/arge-raporlar/2014-yilifaaliyet-raporu.pdf [accessed: 15.12.2019].

The Ministry of Family and Social Policies (2019e). Annual Report 2013-Ministry of Family and 
https://www.ailevecalisma.gov.tr/Uploads/sgb/uploads/pages/arge-raporlar/2013-yilifaaliyet-raporu.pdf [accessed: 15.12.2019].

The Ministry of Family and Social Policies (2019f). Annual Report 2012-Ministry of Family and Social

Policies. https://www.ailevecalisma.gov.tr/Uploads/sgb/uploads/pages/arge-raporlar/2013-yilifaaliyet-raporu.pdf [accessed: 15.12.2019].

The Ministry of Family, Labor and Social Services (2019). Disabled and Elderly Statistics Bulletin. https://ailevecalisma.gov.tr/eyhgm/yayin-kaynak/ [accessed: 10.12.2019].

The Ministry of Family and Social Services, 2021, https://www.aile.gov.tr/, [accessed: 23.09.2021].

The Promotion of Social Assistance and Solidarity Act of 3294 (1986). https://www.mevzuat.gov.tr/MevzuatMetin/1.5.3294.pdf [accessed: 15.12.2019].

To Amend the Decree Having Force of Law Concerning the Organization and Duties of The Ministry of Family and Social Policies and to Some Laws and Decrees Having Force of Law Act of 662 (2011). https://www.resmigazete.gov.tr/eskiler/2011/11/20111102M12.htm [accessed: 15.12.2019].

Turkish Statistical Institute (2019a). Estimations of Population Growth Rate, 1927-1985, Estimations and Projections of Population Growth Rate 1986-2025. http://www.tuik.gov.tr/PreTablo.do?alt_id=1047 (20 December 2019).

Turkish Statistical Institute (2019b). Elderly Statistics. http://www.tuik.gov.tr/ UstMenu.do?metod=kategorist [accessed: 20.12.2019].

World Bank (2020). GDP Per Capita (Current US\$) - Turkey. https://data.worldbank.org/ indicator/NY.GDP.PCAP.CD?locations=TR [accessed: 30.01.2020]. 